\section{DE DE GRUYTER} OPEN
Journal of Intercultural Management

Vol. 6, No. 4, part II, December 2014, pp. 35-47

DOI 10.2478/joim-2014-0055

Katarzyna Olejniczak ${ }^{1}$

Politechnika Częstochowska

\title{
Norms and Values in Family Business Management
}

\begin{abstract}
Family entrepreneurship aiming at multi-generation, in which there is no clear distinction between the family and the business, and family members exert a significant influence on or directly manage a family business, is managed by means of norms and values, passed from generation to generation. Therefore, it is important, in the present unclear market conditions, to present the research results concerning norms and values in family business management from the point of view of the students of the Faculty of Management of Czestochowa University of Technology.
\end{abstract}

Keywords: family entrepreneurship, norms and values

\section{Introduction}

In the changing conditions of the environment, a more and more important role in enterprise management is played by instrumental, individual, social and ethical norms and values. This results from the fact that, nowadays, they are present in all undertaken activities, while setting, most of all, the goals of business activity and the ways of their accomplishment. This means that norms and values in each organization should be recognized and taken into consideration in everyday activity. The significance of norms and values is particularly visible in case of family entrepreneurship where, on the one hand, these values are passed from generation to generation, and on the other, it is important to maintain the balance between family involvement, the accomplishment of goals and the recognized values [Olejniczak 2013, p. 79].

Therefore, the aim of the paper is to present the research results concerning norms and values in family business management. Running a family business

1.k.olejniczak@zim.pcz.pl 
activity is difficult since, apart from enterprise management, it is also necessary to combine family matters with professional ones. Consequently, there appear some untypical challenges, concerning e.g. employing a family member or finding a successor [Kempa 2013, p. 275]. Therefore, it is reasonable to carry out the research aiming at the assessment of the influence of norms and values on family business management from the point of view of the students of the Faculty of Management of Czestochowa University of Technology.

While referring to the problem, the following conditions of the significance of norms and values in family business management, which lay the grounds for the interpretation of the obtain research results, were defined:

- being driven by values is the basic principle of the functioning of family entrepreneurship,

- in family entrepreneurship, it is important to specify norms and behavior in relationships in the company,

- family businesses pay much greater attention to moral standards than nonfamily businesses.

On the basis of the above, the thesis was formulated that norms and values constitute the basis for family entrepreneurship management.

\section{The results of the survey}

The conclusions presented below were formulated on the basis of the obtained results of the survey conducted in January 2014 among the students of year one of extramural studies (second cycle) of the course of Management. 76 students, who are employed, took part in the research, out of whom 36\% were the people holding managerial posts, whereas $64 \%$ - the people holding lower-level positions. Purposefulness of the selection of the research sample is justified, since the respondents (students) are the employed people, who deal with family businesses in their profession. The research tool was the questionnaire including 18 closedended questions, i.e. the ones with previously established responses. It is necessary to indicate that the conducted research was fully anonymous and the participation in the above was voluntary.

54 women and 22 men took part in the research. The analysis of the respondents showed that the majority of them were the people aged up to $25(49 \%)$, then, the people aged $36-50(28 \%)$, and the people aged $25-35(24 \%)$.

In the conducted research the factors referring to norms and values in family business management were the subject of the analysis, the family business in which spouses and the next generation take an active part in enterprise management [Safin 2007, p. 22].

Due to the fact that a family business is acknowledged as a special social and economic phenomenon, and the family is favorable environment for entrepreneurial 
behavior and they constitute the basis for stable functioning of many economies [Nowodziński 2011, p.101], the respondents were requested to answer the question "In your opinion, is a family business a place where:" (Fig. 1).

Figure 1. The significance of a family business in the respondents' opinion

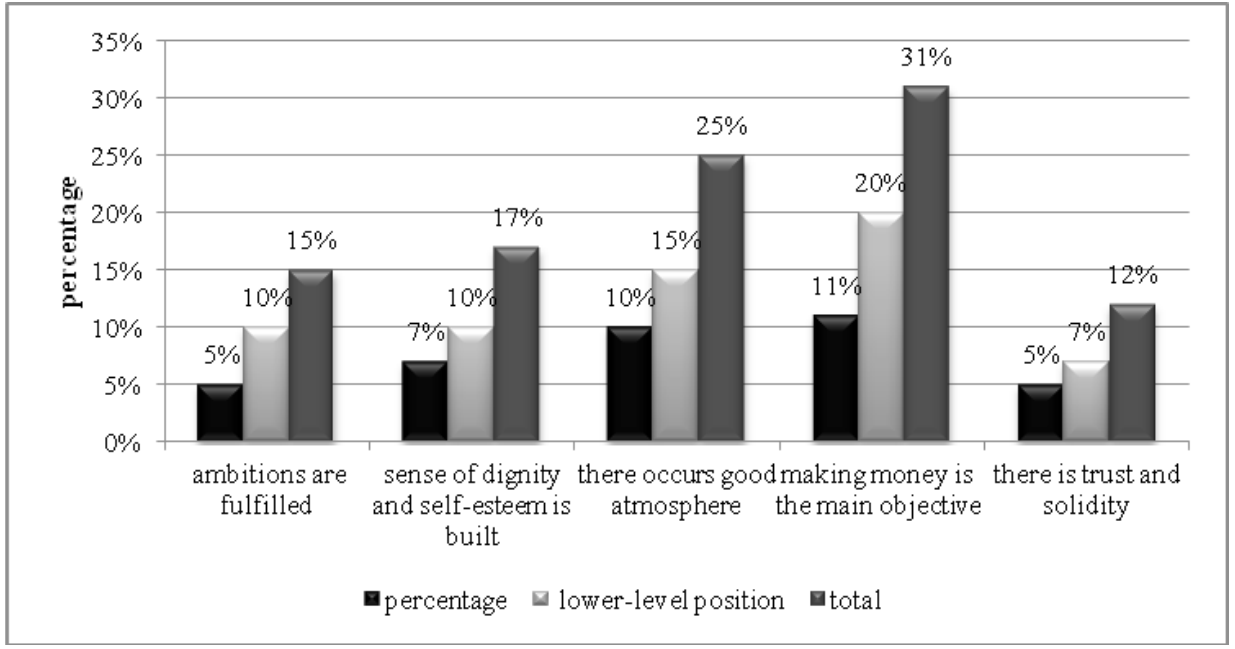

Source: The author's own research based on the survey

According to $31 \%$ of the respondents, a family enterprise is, above all, the place where making money is the priority, and also it is the place in which, due to a family character, there is good atmosphere (25\% of indications). According to $17 \%$ of those questioned, a family business is the place where a sense of dignity and selfesteem is built, where one's own ambitions are fulfilled (15\% of the total number of responses) and where there is trust and solidarity (12\% of indications).

The analysis of the research material showed that, according to $68 \%$ of those questioned, the owners of family businesses get involved in the problems of their employees to a greater extent than in case of workers employed in non-family companies, though:

- $38 \%$ acknowledged that they do get involved but rather rarely,

- $30 \%$ admitted that employees are treated like family members.

$32 \%$ of the respondent express a different opinion, claiming that the owners, no matter what a nature of the company is (family or non-family), do not get involved in their employees' problems since they have no time for that. The detailed distribution of responses is shown in Fig. 2. 
Figure 2. The involvement of the owners of family businesses in the problems of their employees

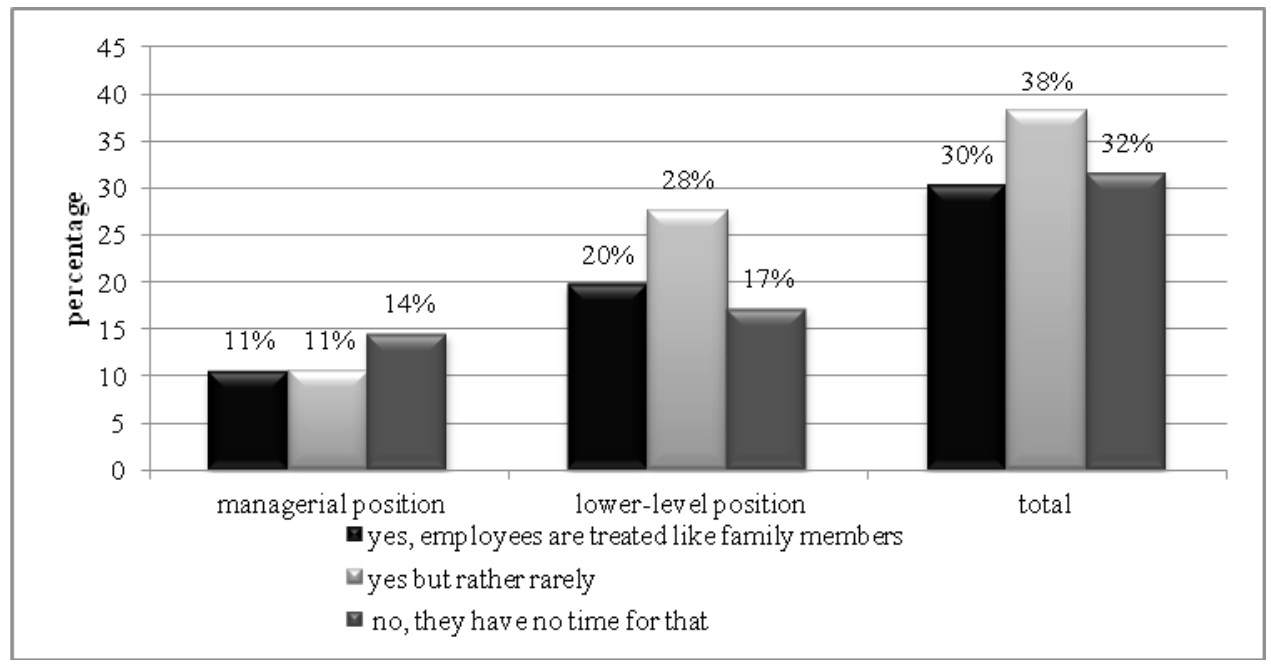

Source: The author's own research based on the survey

At the next stage, the respondents were requested to specify the importance of norms and behavior in relations in a family business, and particularly, the employment of family members or establishing relationships among employees. According to $72 \%$ of those questioned, family businesses should possess specific norms of behavior referring to all relations inside an enterprise, though $8 \%$ express a different opinion and 20\% were not able to express their opinion on the presented problem. The detailed distribution of responses, referring to the employment of family members and also establishing relationships among employees is presented in Table 1.

The data shown in Table 1 show that, according to the $50 \%$ of the respondents, the employment of family members in family businesses is inscribed in ethical standards and has no greater influence on enterprise management. Interestingly, $28 \%$ were not able to express their opinion on the question and $22 \%$ assumed that the employment of family members negatively affects the functioning of the company and is not inscribed in the norms. Moreover, these people claim that the employment of family members brings about many threats like in a relationship between an employer and a family member. 
Table 1. Ethical standards in relations in family businesses

\begin{tabular}{|c|c|c|}
\hline In your opinion, & Number of responses & N\%-76 \\
\hline \multicolumn{3}{|c|}{$\begin{array}{c}\text { is the employment of family members in family businesses inscribed in ethical standards of } \\
\text { running a business }\end{array}$} \\
\hline Yes & 38 & $50 \%$ \\
\hline No & 17 & $22 \%$ \\
\hline Hard to say & 21 & $28 \%$ \\
\hline$\sum$ & 76 & $100 \%$ \\
\hline \multicolumn{3}{|c|}{$\begin{array}{c}\text { is establishing relationships among employees in family businesses inscribed in ethical standard } \\
\text { of running a business }\end{array}$} \\
\hline Yes & 30 & $40 \%$ \\
\hline No & 18 & $24 \%$ \\
\hline Hard to say & 28 & $37 \%$ \\
\hline$\sum$ & 76 & $100 \%$ \\
\hline
\end{tabular}

Source: The author's own research based on the survey

The data presented in Table 1 show that, like in the previous question, the majority of the respondents $(40 \%)$ acknowledged that establishing relationships among employees in family businesses is also inscribed in the norms of running a business in an ethical way, while not affecting the management and functioning of the company. As it is possible to notice, $37 \%$ of the respondents were not able to answer the question whether establishing relationships at work is inscribed in the norms or not, though $30 \%$ of the responses were given by the people holding lower-level positions. $24 \%$ of those questioned acknowledged that establishing relationships among employees is not inscribed in ethical standards and constitutes the barrier to the functioning since it hinders the work control and also increases the risk of conflicts.

From the point of view of the conducted research, it was essential to receive an answer to the question what threats coming from too close relationships may occur in family businesses (Fig. 4). At this point, it is necessary to pinpoint that family business management is more difficult than non-family business management. This results from the fact that managing family entrepreneurship is the management of the company and the family, and each failure in the company is immediately transferred onto the family and every crisis in the family - onto the company (...) Fortunately, the family nature of an enterprise carries not only threats but also opportunities, when the company and the family support each other. A wellmanaged company with a solid foundation in a consistent and loving family has good chances to survive for many generations [Blikle 2012, p. 39] and this transgeneration survival and succession is the main idea in the creation of the family business future [Tomski 2011, pp. 137-150].

Both the managers and lower-level employees stated that the greatest risk coming from too close relationships among employees is non-objective assessment 
of an employee (31\% of indications), followed by, not enforcing obligations as well as using mutual relationships for own benefit - $22 \%$ of indications each. A special attention needs to be drawn to the fact that familiarity does not constitute a big threat in the respondents' opinion, although it negatively affects the relationships inside the company.

Figure 3. Threats from too close relationships among employees

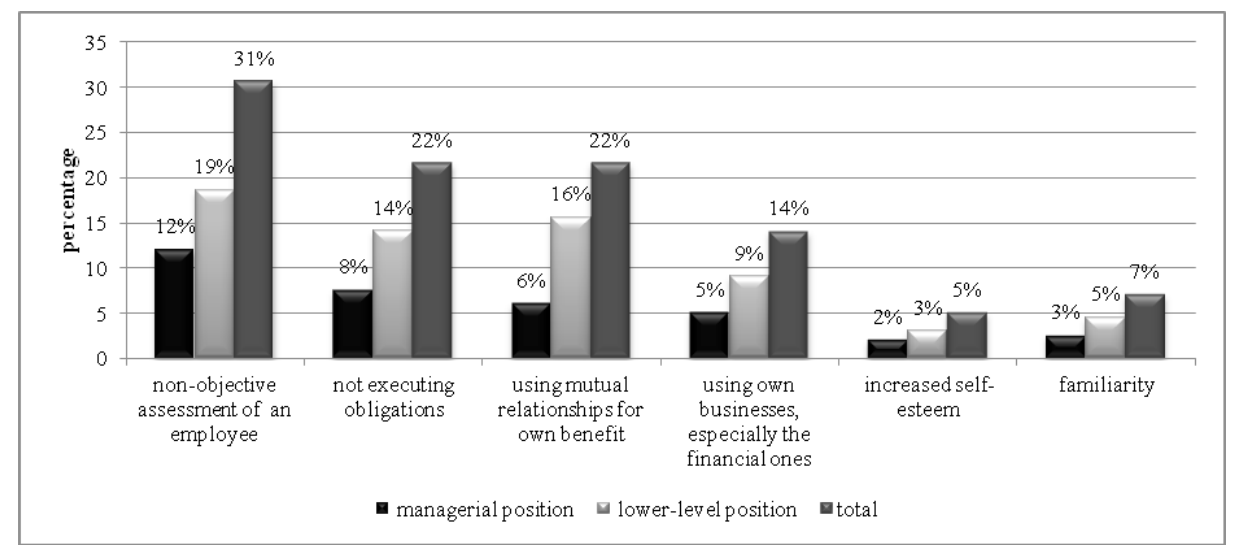

Source: The author's own research based on the survey

In the further part of the research the respondents were asked to indicate in which, out of four relationships, i.e.

- an enterprise owner and a family member (employer - employee),

- a family member and an enterprise owner (employee - employer),

- a family member and the remaining employees (employee - employee),

- an enterprise - a client, where the client is frequently a family member, there occur some ethical dilemmas to the greatest extent (tab. 2).

In spite of the fact that more than a half of the respondents acknowledged that employment of family members in family businesses is inscribed in ethical standards of running a business, it is in the established relationships between an enterprise owner and a family member there occur the greatest ethical dilemmas. Such an opinion was expressed by $46 \%$ of those questioned, whereas $22 \%$ acknowledged that the biggest problems appear in relationships between a family member and the remaining employees and between a family member and an enterprise owner - 18\%.

Table 2. Ethical dilemmas in relationships in family businesses

\begin{tabular}{|c|c|c|}
\hline $\begin{array}{c}\text { In which of the below relationships there occur ethical dilemmas } \\
\text { most frequently: }\end{array}$ & $\begin{array}{c}\text { Number of } \\
\text { responses }\end{array}$ & $\mathrm{N} \%-76$ \\
\hline enterprise owner - family member & 35 & $46 \%$ \\
\hline
\end{tabular}




\begin{tabular}{|c|c|c|}
\hline family member - enterprise owner & 14 & $18 \%$ \\
\hline family member - the remaining employees & 17 & $22 \%$ \\
\hline enterprise - client & 10 & $13 \%$ \\
\hline
\end{tabular}

Source: The author's own research based on the survey

On account of the aim of the conducted research, the respondents were asked "Is being driven by values the basic principle of the functioning of family entrepreneurship?” (Fig. 4), "Can family businesses implement the ethical dimension of business more efficiently than non-family businesses?” (Fig. 5).

Figure 4. The significance of being driven by values in family entrepreneurship

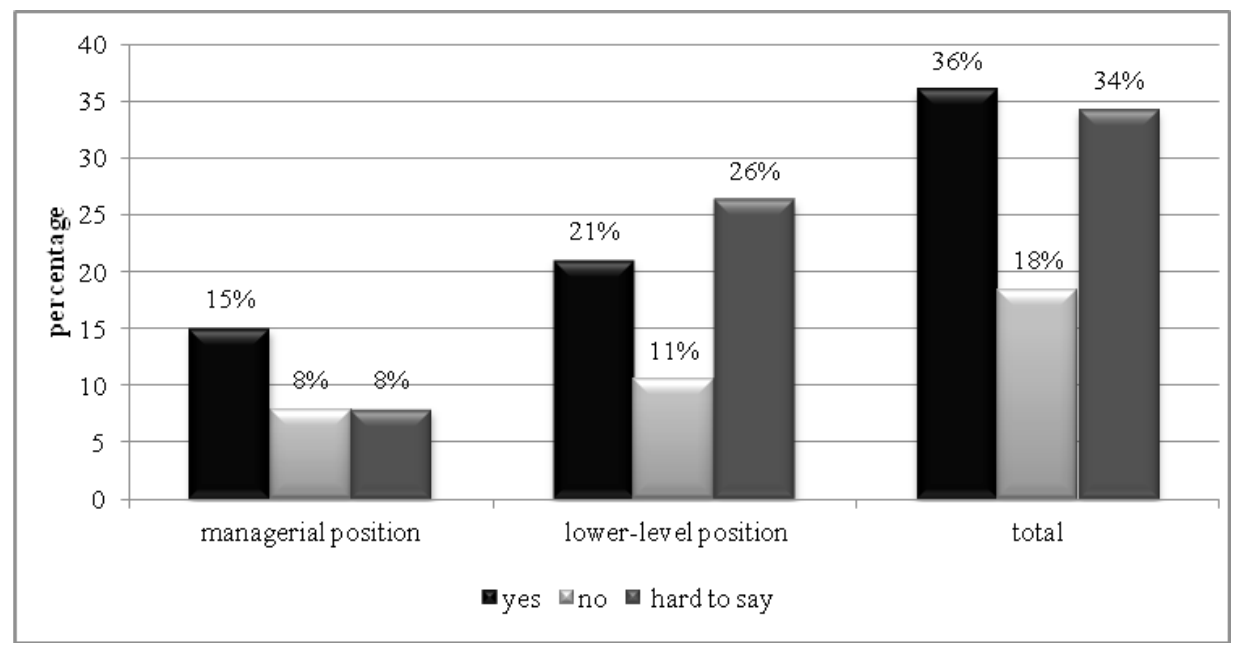

Source: The author's own research based on the survey

While analyzing the data in Fig. 4, it is possible to conclude that $36 \%$ of the total number of the respondents acknowledged that being driven by values in the activity of family businesses is a basic principle of their functioning. A different opinion was expressed by $18 \%$ of those questioned. Interestingly, as much as $34 \%$ of the respondents answered "hard to say". However, taking into consideration the position occupied in the company, the research results are slightly different. While for the majority of people holding managerial positions, being driven by values constitutes a basic principle of functioning, in case of people holding lowerlevel positions, $26 \%$ of those questioned were not able to express their opinion on this question, though, $21 \%$ stated that the values which dominate in family entrepreneurship provide the foundation for family business.

The vast majority (61\%) of those questioned think that family businesses may run their business activity, based on norms and ethical standards, more efficiently 
than non-family enterprises (Fig. 5). $25 \%$ of the respondents were not able to state their opinion on the above research problem, whereas according to $14 \%$, both family businesses and non-family ones implement the ethical dimension of business in a similar way.

The confirmation of the above is the fact that the vast majority (68\%) of those who took part in the research express the opinion that family businesses pay much greater attention to moral values, ethical standards or corporate social responsibility than non-family businesses, though:

- $30 \%$ claim that these are the most important assumptions a family business is based on,

- $38 \%$ of those questioned state that these are the ones of more important assumptions of the functioning of the company.

According to $32 \%$ of the respondents, the family nature of business does not count while developing the activities which are socially responsible or while being driven by ethical and moral values.

Figure 5. Implementation of the ethical dimension of business by family entrepreneurship

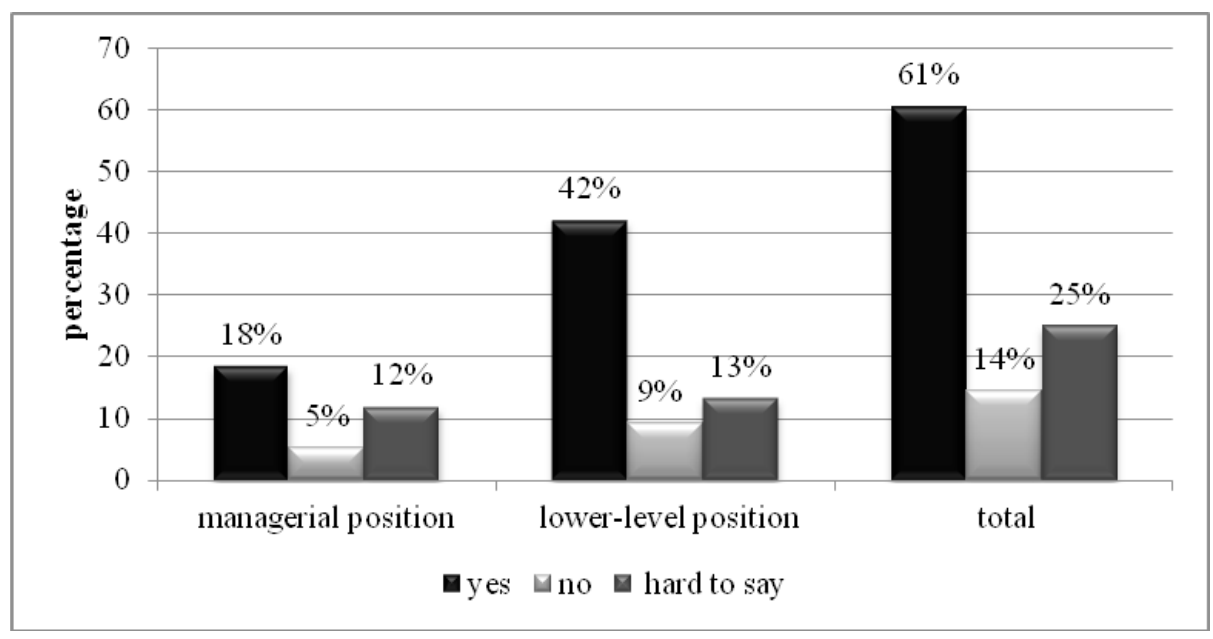

Source: The author's own research based on the survey

A similar structure of responses is for the question referring to responsibility for the decisions and activities taken in family entrepreneurship. According to $43 \%$ of those questioned, family enterprises, due to their values passed from generation to generation, are more responsible for their activities than non-family businesses. Undoubtedly, it is connected with the fact that the activities of family entrepreneurship are associated with trust, which positively correlates with: regarding 
the connection between own business and business of the company, willingness to share knowledge, ability of teamwork, loyalty towards the company, awareness of the enterprise mission and strategy, interpersonal skills, openness towards contacts with the environment, ambitions and need for achievements, orientation towards a customer, atmosphere favorable for creativity and experimenting, atmosphere favorable for confessing ignorance and mistakes, attitude of aiming at development [Glińska-Neweś 2007, pp. 222-228]. 37\% of those questioned were not able to state their opinion on the presented research problem, though they acknowledged that being a responsible entrepreneur on the market is an asset for a family business.

On account of the fact that values and norms constitute the foundation in family business management, the respondents were asked whether the implementation of family values provides the sense of trust, safety and certainty, and also whether a family business, while referring to their traditions and values, attracts clients (Tab. 3).

The data presented in Table 3 unambiguously indicate that the vast majority of the respondents (61\%) state that values (norms, patterns, customs) passed from generation to generation, create the sense of trust, safety and certainty, particularly among the employed workers. Undoubtedly, it is connected with the fact that family businesses are regarded in family terms, which are associated with durability, trust, attachment, mutuality, help in difficult situations, family atmosphere, being driven by values which, in turn, amounts to relationships at work, in which there are visible values like: mutuality, help, involvement and responsibility. Unfortunately, not all the respondents shared the opinion that family values influence the quality of work. A different opinion is expressed by $17 \%$ of those who took part in the research, whereas $22 \%$ were not able to state their opinion on the question included in the questionnaire.

Table 3. Family values and the feelings of stakeholders in family businesses

\begin{tabular}{|c|c|c|}
\hline In your opinion, & Number of responses & $\mathrm{N} \%-76$ \\
\hline \multicolumn{3}{|c|}{$\begin{array}{l}\text { does the implementation of family values create the sense of trust, safety and } \\
\text { certainty in a family business? }\end{array}$} \\
\hline Yes & 46 & $61 \%$ \\
\hline No & 13 & $17 \%$ \\
\hline Hard to say & 17 & $22 \%$ \\
\hline$\sum$ & 76 & $100 \%$ \\
\hline \multicolumn{3}{|c|}{ do family businesses attract clients while referring to their traditions and family values? } \\
\hline Yes & 52 & $68 \%$ \\
\hline No & 7 & $9 \%$ \\
\hline Hard to say & 17 & $22 \%$ \\
\hline$\sum$ & 76 & $100 \%$ \\
\hline
\end{tabular}

Source: The author's own research based on the survey 
$68 \%$ of the respondents state that family businesses attract their clients while referring to traditions and family values. As A. Blikle indicates, it is connected with honor of the family, clients see not only the company but a specific family, the people who testify to the reliability of their company with their honor. [Blikle, 2012, s. 46]. The fact that the respondents regard the products of family businesses as being of good quality, healthy and solid, deserves a special attention. For $9 \%$ of those questioned, referring to tradition and family values is not a factor determining the choice of products or services. On the other hand, $22 \%$ find it hard to specify whether such activities on the side of family entrepreneurship attract clients.

While performing the analysis of norms and values in family business management, the respondents were asked to indicate which, out of three groups of values (ethical, business and family) are the most significant for family businesses (Fig. 6).

Figure 6. Values of a family business

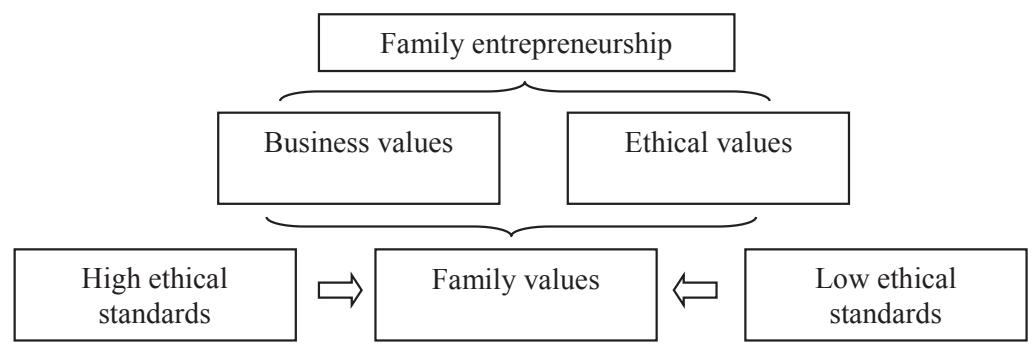

Source: [Olejniczak 2013, p. 83].

In the light of the conducted empirical studies, it turned out that, according to $49 \%$ of those questioned, business values are the most important, and among them the following:

- quality $-22 \%$ of indications,

- effectiveness $-21 \%$ of indications,

- efficiency $-19 \%$ of indications.

The detailed list of business values in family business management in the respondents' opinion is presented in Fig. 7.

Apart from business values in family business management there are family values (39\% of indications) and ethical values (12\% o indications). However, family values, particularly the ones passed from generation to generation, may have a dual dimension, i.e. the first one - creating high ethical standards, referring to pursuing norms by family members, and the other dimension, creating low ethical standards, connected with unethical behavior of family members. In spite of the fact that ethical standards do not constitute the most important norms in family 
business management, the respondents were asked what ethical values influence the functioning of the enterprise (Fig. 8).

Figure 7. Business values in family business management

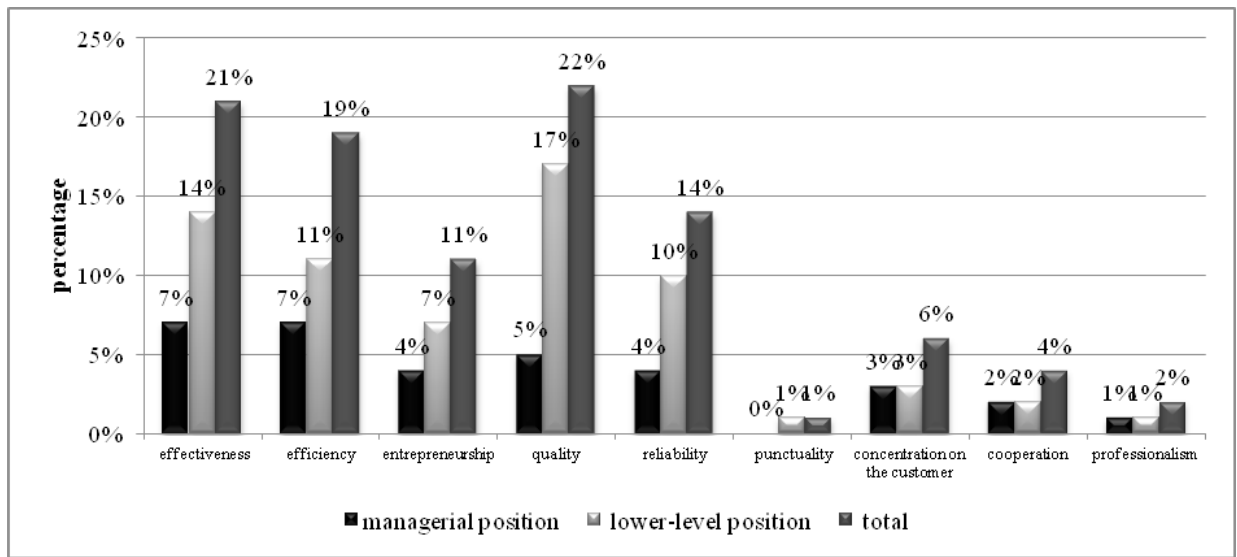

Source: The author's own research based on the survey

Figure 8. Ethical values in family business management

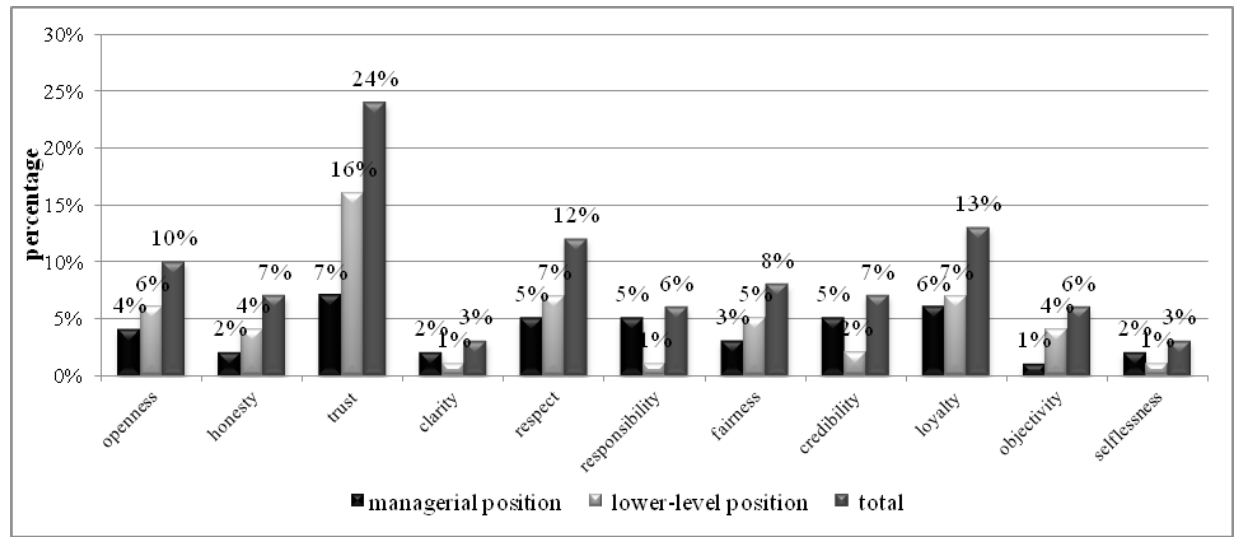

Source: The author's own research based on the survey

The analysis of the collected empirical material showed that the basic ethical value is trust - $24 \%$ of indications. The remaining values are at a similar level, though such ethical values as: loyalty, respect and openness deserve a special attention. In the last part of the research, the respondents were asked to specify the influence of norms and values on family business management (Tab. 4). 
Table 4. The influence of norms and values on family business management

\begin{tabular}{|l|l|l|}
\hline In your opinion, & $\begin{array}{l}\text { Number } \\
\text { of } \\
\text { responses }\end{array}$ & No-76 \\
\hline defining key values in family businesses & 31 & $41 \%$ \\
\hline creates its organizational culture & 8 & $11 \%$ \\
\hline increases competitive potential & 20 & $26 \%$ \\
\hline guarantees the continuity of recognizing values in the future & 6 & $8 \%$ \\
\hline influences more effective succession & 11 & $14 \%$ \\
\hline $\begin{array}{l}\text { brings about the increase in the effectiveness of employees' } \\
\text { activity }\end{array}$ & 76 & $100 \%$ \\
\hline$\sum$ & \multicolumn{2}{|l}{} \\
\hline system of values in a family business brings about that: & $33 \%$ \\
\hline $\begin{array}{l}\text { family members identify their way of life with the company's } \\
\text { development and prosperity }\end{array}$ & 25 & $30 \%$ \\
\hline $\begin{array}{l}\text { family members advocate for continuity and continuation of the } \\
\text { project }\end{array}$ & 23 & 20 \\
\hline family members aim at preserving family tradition & 8 & $11 \%$ \\
\hline unites the family around the company's activity & 76 & $100 \%$ \\
\hline$\sum$ &
\end{tabular}

Source: The author's own research based on the survey

In the light of the conducted empirical studies, it turned out that defining key values in family businesses creates, most of all, organizational culture (41\% of indications). As K. Lukasik underlines, organizational culture represents specific ideas and values, which are common for the group of people working in a given family business, irrespective of its size or ownership. These values are revealed by symbols (e.g. brand, logo), tales (records, stories, anecdotes), slogans, rituals and heroes of the company. Therefore, it is a kind of a set of features which allow employees to understand what an organization stands for, how it works and what it regards as important [Łukasik 2013, p. 33]. Moreover, defining key values acknowledged in everyday activity guarantees following them in the future. Such an opinion was expressed by $26 \%$ of the respondents. While analyzing the data referring to the influence of the value system, it is possible to notice that possessing such a system brings about, most of all, that family members, on the one hand, identify their way of life with the company's development and prosperity $33 \%$ of indications), and on the other, they advocate for the continuity and continuation of the project (30\% of indications). The fact that, due to specific values and norms, family members aim at preserving family traditions, is also undeniable. 


\section{Conclusions}

The considerations presented above show that family entrepreneurship is not only aiming at achieving economic goals (profit growth, increase in market share, achievement and realization of sales targets etc.) but it is basically the place where ambitions are fulfilled and dignity and self-esteem is built. This results from the fact that family businesses develop along with the family, which is connected with their specificity, by means of which there are created norms and values passed from generation to generation. Moreover, these values are more deeply rooted than in case of non-family businesses. Therefore, it is possible to conclude that norms and values constitute the basis for the functioning and, simultaneously, the management of a family business. On the basis of the conducted research, it is possible to state that the owners of family businesses treat their employees like family members, while getting involved in their problems. What is more, employing family members or establishing relationships among employees is inscribed in ethical norms and values, though most threats come from the relationship between an enterprise owner and a family member. The conducted research also indicated that family businesses may run their activity, based on ethical norms and values, more efficiently than nonfamily businesses, while being more responsible for their activities and decisions.

\section{References}

Blikle A. (2012), Specyfika zarzadzania $w$ firmach rodzinnych, W: Firma $w$ rodzinie czy rodzina w firmie, Metodologia wsparcia firm rodżinnych, Polska Agencja Rozwoju Przedsiębiorczości, Warszawa, s. 39.

Glińska-Neweś A. (2007), Kulturowe uwarunkowania zarzqdzania wiedzq w przedsiębiorstwie, TNOIK „Dom Organizatora”, Toruń, ss. 222-22.

Kempa E. (2013), Miejsce firm rodżinnych w sektorze MSP, Przedsiębiorczość i Zarządzanie, tom XIV, zeszyt 6, część I, Wydawnictwo SAN, Łódź, s. 275.

Lukasik K. (2013), Kultura organizacyjna $i$ jej wptyw na jakość funkcjonowania firm rodzinnych, Przedsiębiorczość i Zarządzanie, tom XIV, zeszyt 6, część I, Wydawnictwo SAN, Łódź, s. 33 .

Nowodziński P. (2011), Rola kultury organizacji w ksz̨taltowaniu strategii przedsiębiorstwa rodzৃinnego, Przedsiębiorczość i Zarządzanie, t. XII Wydawnictwo SAN, Lódź, s.101.

Olejniczak K. (2013), Family Entrepreneurship and Business Ethics - the Selected Aspects. W: Wspótczesne determinanty funk.cjonowania matych i średnich prz̨edsiębiorstwem. Red. nauk. O. Seroka-Stolka, Sekcja Wydawnicza Wydziału Zarządzania Politechniki Częstochowskiej, Częstochowa, ss. 79-83.

Safin K. (2007), Przedsięiorstwo rodzinne, Wydawnictwo Akademii Ekonomicznej we Wrocławiu, Wrocław, ss. 21-22.

Tomski P. (2011), Programowanie przyszłości biznesu w oparciu o więi rodzinne - wybrane problemy sukesesji, Przedsiębiorczość i Zarządzanie, t. XII, z. 7, Seria SWSPiZ, Wydawnictwo SAN, Łódź, s. 137-150. 